\title{
Assessment of Natural Groundwater Recharge in Terengganu, Malaysia
}

\author{
Musa Garba Abdullahi", Mohd Khairul Amri Kamarudin", Mohd Ekhwan Toriman*, Muhammad Barzani \\ Gasim $^{\#}$, Azizah Endut ${ }^{\#}$, Iliyasu Garba ${ }^{1}$ \\ ${ }^{\#}$ East Coast Environmental Research Institute, Universiti Sultan Zainal Abidin, Gong Badak Campus Terengganu, 21300, Malaysia \\ E-mail:musagarbaabdullahi@yahoo.com,mkhairulamri@unisza.edu.my,drbarzani@gmail.com,enazizah@unisza.edu.my \\ "School of Social, Development and Environmental Studies, Faculty of Social Sciences and Humanities, National University of Malaysia, \\ Bangi, Selangor, 43600, Malaysia \\ E-mail: ikhwan@ukm.edu.my \\ ${ }^{I}$ Department of Geology, Kano University of Science and Technology, Wudil, Kano, Nigeria \\ E-mail:mgabdul55@gmail.com
}

\begin{abstract}
Estimation of groundwater recharge is essential for efficient groundwater resources management, for domestic uses and irrigation purposes in the study area. The present research entails the assessment of natural groundwater recharge in Terengganu Malaysia. Estimation of recharge by whatever method is usually subjected to a large uncertaintyand errors. However, this research attempt to derive an empirical relationship to determine the groundwater recharge from rainfall based on seasonal groundwater balance studies using the data obtained from 2000-2001 to 2011-2012. This empirical relationship similar to Chaturvedi formula was derived by fitting the estimated values of rainfall recharge, and the corresponding values of rainfall in the monsoon season through the non-linear regression techniques. The result shows that the proportion of variance explained was found to be $89.52 \%$, the recharge of groundwater commences at $P=15.28$ inches and the relative errors was found to range from 3.680 to $46.020 \%$.
\end{abstract}

Keywords — groundwater; rainfall; recharge; monsoon season; water balance; empirical relation

\section{INTRODUCTION}

Groundwater is vital natural resources to human activities which are extracted from the ground. The amount of water extracted without causing depletion in groundwater, depend upon the nature of the aquifer and the groundwater recharge. Thus, a quantitative measurement of space and time for groundwater recharge is a pre-requisite for the operating groundwater resources system. Rainfall is the fundamental source of groundwater recharge, the amount of recharge depends upon the nature of rainfall, the duration it takes, the nature of the soil, the antecedent soil moisture and usually the depth to the water table. When rain falls, the amount of water moves as moisture in the unsaturated zone which was controlled by suction pressure, hydraulic conductivity, moisture content and gravity will fill the saturated zone after passing the water table is termed as "groundwater recharge". Recharge has been defined as the process of addition of water to the saturated zone.
It is very important to determine the rate of aquifer replenishment but is the most difficult task to measure without a number of errors. Recharge estimation has no reliable techniques that will lead to the accurate results, but it can be based on a wide variety of models which are designed to represent the actual physical processes. The most common methods use for estimation of natural groundwater recharge include groundwater balance method, soil water balance method, zero flux plane method, onedimensional soil water flow model, and inverse modeling techniques and isotopes and solute profile techniques [1]-[4].

In Malaysia, rainfall is the most reliable source for groundwater recharge. The most commonly used methods for estimation of natural groundwater recharge in Malaysia are Chloride Mass Balance (CMB), empirical method and groundwater level fluctuation method. According to the studies carried out by different scientists and organizations in some part of the country, including the neighboring state of the study area (Kelantan) derived a correlation for groundwater level fluctuation and rainfall, some empirical 
relationship has been derived for computation of natural recharge to groundwater from rainfall [5], [6].

In [1] assessed the natural groundwater in Upper Ganga Canal command area. An empirical relationship was used to determine groundwater recharge from rainfall in the study area based on the seasonal groundwater balance study carried out for a number of years. In [6] estimate groundwater recharge using empirical method in the tropical zone (Selangor, Malaysia), in which the groundwater recharge coefficient and effective rainfall were determined. The results showed that groundwater recharge was $326.39 \mathrm{~mm}$ per year, and recharge coefficient was found to be $18 \%$ of the study area.

In [7] used Chlorine Mass Balance to estimate the natural groundwater recharge in the North Kelantan River catchment. The result illustrated that estimate of deep percolation using a CMB method range from $17 \%$ to $30 \%$ of precipitation (between 475 and $769 \mathrm{~mm} / \mathrm{yr}$.) in the study area [6]. However, to the best of the author's knowledge, there is no similar work carried out in Terengganu Malaysia. In this paper, an attempt has been made to assess and derived an empirical relationship to determine groundwater recharge from rainfall in Terengganu, Malaysia based upon seasonal groundwater balance study carried out for a year 2000-2001 to 2011-2012.

\section{MATERIAL AND METHOD}

\section{A. Study Area}

Terengganu is a state of Malaysia. It is situated in the coordinate $4{ }^{\circ} 45^{\prime} \mathrm{N}$ latitude and 1030' E longitude, which is located in the north-eastern of Peninsula Malaysia. Terengganu is bordered on the northwest by Kelantan, the southwest by Pahang and the east by the South China Sea. The state has a total area of $13,035 \mathrm{~km}^{2}(5,033 \mathrm{sq} . \mathrm{mi})$ and the total population of $1,015,776$ as for the 2010 census with a density of $78 \mathrm{~km}^{2}$ (200/sq. mi) [8], [9].

Climatically, like the other states of the country, Terengganu has a tropical monsoon climate which is generally fairly hot and humid all year around. The temperature is relatively uniform within the range of $21^{\circ} \mathrm{C}$ to $32^{\circ} \mathrm{C}$ throughout the year. During the months of January to April, the weather is generally dry and warm. Humidity is consistently high which approximately $80 \%$ of daytime and slightly cooler after sunset. Nevertheless, the sea breeze from the South China Sea has somehow moderating the humidity in offshore areas, while altitude and lush forest trees and plants has cooled the mountain and rural areas.

Terengganu has characterized by two main types of monsoon, the southwest monsoon season, which is usually established in the latter half of May or early June and end in September. The northeast monsoon, which usually starts in November and end in March. Terengganu receives heavy rainfall of approximately between $2034 \mathrm{~mm}$ to $2504 \mathrm{~mm}$ per year, which can easily break the bank of the rivers and cause overbank discharge. When the northeast monsoon blows between Novembers to January, some areas suffer flooding at this time.

However, in the whole of Peninsular Malaysia, the northeast monsoon is the major rainy season which develops in conjunction with cold air outbreaks from Siberia. It produces heavy rains which often cause severe floods in the east coast states of Terengganu, Kelantan, Pahang and east Johor in Peninsular Malaysia [10]-[19].

The aquifer in the study area is mostly covered with Indogangetic alluvium and is somehow deep. They are tapped mostly by private devices such as tube wells, pump sets rahats and the rest which are found mostly in the rural areas for their domestics used as well as for irrigation purposes. Some places have shallow aquifer ranges from 20 to 30 meters, which easy to dig for private purposes. But, for the state were dogs up to 100 to 130 meters. The groundwater fluctuation varies from place to place, usually 0.2 to 0.8 meters between the pre-monsoon to post-monsoon season.

\section{B. Model Design and Sensitivity}

Estimation of parameters is subject to a degree of uncertainty which is associated with the conceptual model, data and parameters for to be observed [20]. Uncertainty estimation is dealt with calibration and estimation procedures and may be affected by uncertainty due to weakness in determining the exact parameter either by inadequate or inappropriate spatial and temporal distribution of the observed data and boundary conditions.

\section{Chaturvedi Formula}

Based on the water level fluctuations and rainfall amounts in India (Ganga Yamuna), Chaturvedi derived an empirical relation in 1936 to arrive at the recharge as a function of annual precipitation.

$$
R=2.0(P-15)^{0.4}
$$

where $\mathrm{R}=$ net recharge due to precipitation during the year in inch and $\mathrm{P}=$ annual precipitation in inch. This formula was later modified by further work at U.P Irrigation Research Institute as

$$
\mathrm{R}=1.35(\mathrm{P}-14)^{0.5}
$$

It is now used for estimation of groundwater recharge due to rainfall worldwide According to this relation, it may be noted that there is a lower limit of the rainfall below which the recharge due to rainfall is zero. Therefore, the percentage of rainfall recharge will be from zero at $\mathrm{P}=14$ inches to $18 \%$ at $\mathrm{P}=28$ inches and can also decrease. In this formula, the lower limit account for the runoff, soil moisture deficit, interception and evaporation losses. This is also applicable to a certain limit of the study area, depending on the nature of the soil.

\section{Groundwater Balance Method}

The impact of man activities in the hydrologic cycle and the quantitative estimates of water resources is essential and can be done by water balance techniques. This water balance approach can be used to make a quantitative evaluation of water resources and its dynamic behavior under the influence of human activities. Water balance refers to the ways in which an organism maintains water in dry or hot conditions. The study of water balance is defined as the systematic presentation of data on the supply and use of 
water within a geographical region for a specified period [1], [16]. The basic component of water balance is

Input to the system - output from the system = Change in storage of the system over a period of time.

The inflow and outflow component of the groundwater balance equation at a time $\Delta \mathrm{t}$ is given by

$$
\mathrm{R}_{i}+\mathrm{R}_{c}+\mathrm{R}_{r}+\mathrm{R}_{t}+\mathrm{S}_{i}+\mathrm{I}_{g}=\mathrm{E}_{t}+\mathrm{T}_{p}+\mathrm{S}_{e}+\mathrm{O}_{g}+\mathrm{A}_{s}
$$

where $R_{i}=$ Recharge from field irrigation, $R_{c}=$ Recharge from canal seepage, $\mathrm{R}_{\mathrm{r}}=$ Recharge from rainfall, $\mathrm{R}_{\mathrm{t}}=$ Recharge from tanks, $S_{i}=$ Influent seepage from the river, $I_{g}$ = Inflow from another basin, $\mathrm{E}_{\mathrm{t}}=$ Evapotranspiration, $\mathrm{T}_{\mathrm{p}}=$ Draft from groundwater, $\mathrm{S}_{\mathrm{e}}=$ Effluent seepage to rivers, $\mathrm{O}_{\mathrm{g}}=$ Outflow to other basin and $\Delta_{\mathrm{s}}=$ Change in groundwater storage.

Equation (3) is a suitable method for groundwater balance estimation, especially in an unconfined aquifer where the boundaries of an area of the studies do not represent streamline. However, the lateral inflow and outflow (Ig and $\mathrm{Og}$ ) of the groundwater crossing the area boundaries will be accounted in the balanced equation [20]. Also, specific yield Sy is one of the factors influencing the changes in the water table of the area in which fluctuation is occurring. It has been observed that sy changes with the change in depth of the water table, especially in the shallow areas in which the water tables is less than 3 meters deep. In this area, when the water table drops, some part of it will be retained by the soil particles. When the water rises, the air can be trapped in the vicinity that is filling with water. However, sy for rising water is generally less than that of falling water table.

Wherever possible, all the elements of the water balance equation are computed using independent methods even though some errors most occur in due processes because of the shortcomings of the techniques used. The water balance equations mostly do not balance even if all the elements are computed using independent methods. The discrepancy of water balance is taken as a residual term of the water balance equation, and will be included in the estimation of the values of components which are not taken into account. However, obtained the impossible to compute the value of a balance component, the component may be evaluated as a residual term in the water balance equation.

In the study area, water balance can be computed for any time interval because most of the rainfall occurs in a part of the year. It is desirable to conduct a water balance study of the monsoon period and no-monsoon period. In such situation, the study will be from time of maximum water table elevation to the time of minimum water table elevation as the non-monsoon period, and at the time for a maximum water table at the time of minimum water table elevation in a monsoon period as well. In Terengganu, Malaysia, the rainiest period can be taken from November to February and all the rest of months will be a moderate or partial rain. Therefore, it is preferable to use a complete data for a cycle covering from the wet and dry year. Equation (3) is very essential for covering both the area of study and the period for which the balance is assessed.

In area like the study area in which the monsoon season come with heavy rainfall, the water balance approach is the most suitable method to be applied in assessing the water balance study and is preferable to compute the season separately (monsoon and non-monsoon season) by the following steps

- Years must be divided into monsoon and non-monsoon period

- The components of the water balance equation other than rainfall recharge for the monsoon period must be estimated using the available hydrological and meteorological data; and employing the subsequent methods for estimation

- The rainfall recharge and recharge coefficient will be estimated and the estimates in (ii) above must be substituted in the water balance equation. Hence, this estimate with those given by other empirical relations will be compared.

- For the non-monsoon period, all the components of the water balance equation, including the rainfall recharge which calculated using a recharge coefficient value obtained through the water balance of the monsoon season will be estimated. The rainfall recharge will be very small in this case. The balance between the left and the right sides of the equation will indicate that the overall recharge from all the sources of recharge and discharge has been quantified with a good degree of accuracy.

\section{RESULTS AND DISCUSSION}

When the rain fell on the ground and percolated into the soil, part of it will be used to fill the soil moisture deficiency and the remaining moves in the water table. The part of the rain infiltrates and reaches the water table is called recharge from rainfall to the aquifer. It depends upon hydrometeorological and topographic factors such as soil texture; depth to the water table, vegetation and urbanization [21][23].

The groundwater balance for the study area was carried out season wise for monsoon (northeast monsoon), which occur in November and ends usually in March. For nonmonsoon (known as southwest monsoon) occurs between June to September. The data used to cover from 2000-2001 to 2011-2012, and followed the essential steps by [24].

The components of the groundwater balance equation with the exception of rainfall recharge were estimated using various hydrological and meteorological information and techniques. The rainfall recharge for monsoon seasons of these years of study was computed by substituting these estimates in the groundwater balance equation. Table I shows the rainfall recharge in the monsoon seasons of all the study year as well as the recharge coefficients. 
TABLE I

GROUNDWATER RECHARGE FROM RAINFALL

\begin{tabular}{|c|c|c|c|c|}
\hline S/N & Year & $\begin{array}{c}\text { Mean Rainfall in the } \\
\text { Monsoon Season (Inch) }\end{array}$ & $\begin{array}{c}\text { Groundwater Recharge from } \\
\text { Rainfall in the Monsoon Season (Inch) }\end{array}$ & $\begin{array}{c}\text { Recharge } \\
\text { Coefficient }\end{array}$ \\
\hline 1 & $2000-2001$ & 50.559 & 10.609 & 0.210 \\
\hline 2 & $2001-2002$ & 35.244 & 10.316 & 0.292 \\
\hline 3 & $2002-2003$ & 45.841 & 10.010 & 0.218 \\
\hline 4 & $2003-2004$ & 44.506 & 10.227 & 0.230 \\
\hline 5 & $2004-2005$ & 41.801 & 10.113 & 0.242 \\
\hline 6 & $2005-2006$ & 38.837 & 10.096 & 0.260 \\
\hline 7 & $2006-2007$ & 33.227 & 10.109 & 0.304 \\
\hline 8 & $2007-2008$ & 47.800 & 10.180 & 0.213 \\
\hline 9 & $2008-2009$ & 37.339 & 10.244 & 0.274 \\
\hline 10 & $2009-2010$ & 35.191 & 10.330 & 0.294 \\
\hline 11 & $2010-2011$ & 31.803 & 9.837 & 0.309 \\
\hline 12 & $2011-2012$ & 35.903 & 10.220 & 0.285 \\
\hline
\end{tabular}

From the above table, it was observed that the recharge coefficient varied from 0.210 to 0.309 and was calculated as the ratio of recharge by rainfall against rainfall in the monsoon season (recharge/rainfall ratio). It is also indicated that rainfall gives almost equal recharge to the groundwater with a slightly different from the year 2000 to 2012 in Terengganu Malaysia. The recharge is not linearly proportional but most of the year with high rainfall have somehow high recharge. The years that have low recharge (2010-2011) also have lower rainfall.

For non-monsoon seasons, unaccounted water were calculated using the relation as (inflow-outflow-change in groundwater storage). The discrepancy was found to be less than 90 million cubic meters in all the cases of the study area of area of $13,035 \mathrm{~km} 2(5,033 \mathrm{sq}$. mi). The total population of
$1,015,776$ and the total quantity of water involved, where this is a reasonable unaccounted water. Therefore, the overall water balance has to be considered to avoid all errors [23].

The empirical relationship similar to Chaturvedi formula was derived by fitting the estimated values of rainfall recharge, and the corresponding values of rainfall in the monsoon season through the non-linear regression techniques [24].

$$
R=0.63(P-15.28)^{0.76}
$$

where $R=$ Groundwater recharge from rainfall in the monsoon season (inch) and $\mathrm{P}=$ Mean rainfall in the monsoon season (inch).

TABLE III

RELATIVE ERRORS WITH PROPOSEd RELATIONSHIP

\begin{tabular}{|c|c|c|c|c|c|}
\hline \multirow{2}{*}{$\mathbf{S} / \mathbf{N}$} & \multirow{2}{*}{ Year } & \multirow{2}{*}{$\begin{array}{l}\text { Mean Monsoon } \\
\text { Rainfall P (inch) }\end{array}$} & \multicolumn{2}{|c|}{ Rainfall Recharge During the Monsoon Season, R (inch) } & \multirow{2}{*}{$\begin{array}{c}\text { Relative } \\
\text { Error }(\%)\end{array}$} \\
\hline & & & Groundwater Balance Study & Proposed Relationship $R=0.63(P-15.28)^{0.76}$ & \\
\hline 1 & $2000-01$ & 50.559 & 10.609 & 9.450 & 10.925 \\
\hline 2 & 2001-02 & 35.244 & 10.316 & 6.131 & 40.568 \\
\hline 3 & 2002-03 & 45.841 & 10.010 & 8.474 & 15.345 \\
\hline 4 & 2003-04 & 44.506 & 10.227 & 8.191 & 19.908 \\
\hline 5 & 2004-05 & 41.801 & 10.113 & 7.608 & 24.770 \\
\hline 6 & 2005-06 & 38.837 & 10.096 & 6.951 & 31.151 \\
\hline 7 & 2006-07 & 33.227 & 10.109 & 5.654 & 44.070 \\
\hline 8 & 2007-08 & 47.800 & 10.180 & 8.883 & 12.741 \\
\hline 9 & 2008-09 & 37.339 & 10.244 & 9.867 & 3.680 \\
\hline 10 & 2009-10 & 35.191 & 10.330 & 6.119 & 40.765 \\
\hline 11 & 2010-11 & 31.803 & 9.837 & 5.310 & 46.020 \\
\hline 12 & 2011-12 & 35.903 & 10.220 & 6.284 & 38.513 \\
\hline
\end{tabular}


TABLE IIIII

RELATIVE ERRORS WITH CHATURVEDI FORMULA

\begin{tabular}{|c|c|c|c|c|c|c|c|}
\hline \multirow[b]{2}{*}{$\mathbf{S} / \mathbf{N}$} & \multirow[b]{2}{*}{ Year } & \multirow{2}{*}{$\begin{array}{l}\text { Mean } \\
\text { Monsoon } \\
\text { Rainfall, } \\
\text { P (inch) }\end{array}$} & \multirow{2}{*}{$\begin{array}{l}\text { Rainfall Recharge } \\
\text { from Groundwater } \\
\text { Balance Study } \\
\text { (inch) }\end{array}$} & \multicolumn{2}{|c|}{$\begin{array}{l}\text { Chaturvedi Formula } R=2.0(P- \\
15)^{2 / 5}\end{array}$} & \multicolumn{2}{|c|}{$\begin{array}{l}\text { Modified Chaturvedi Formula } R= \\
\qquad 1.35(P-14)^{1 / 2}\end{array}$} \\
\hline & & & & $\begin{array}{c}\text { Rainfall } \\
\text { Recharge } \\
\text { (inch) }\end{array}$ & $\begin{array}{c}\text { Relative } \\
\text { Error } \\
(\%)\end{array}$ & $\begin{array}{l}\text { Rainfall } \\
\text { Recharge } \\
\text { (inch) }\end{array}$ & $\begin{array}{c}\text { Relative } \\
\text { Error } \\
(\%)\end{array}$ \\
\hline 1 & 2000-01 & 50.559 & 10.609 & 8.345 & 21.340 & 8.163 & 23.056 \\
\hline 2 & 2001-02 & 35.244 & 10.316 & 6.661 & 35.430 & 6.222 & 39.686 \\
\hline 3 & 2002-03 & 45.841 & 10.010 & 7.883 & 21.249 & 7.618 & 23.896 \\
\hline 4 & 2003-04 & 44.506 & 10.227 & 7.745 & 24.270 & 7.456 & 27.095 \\
\hline 5 & 2004-05 & 41.801 & 10.113 & 7.452 & 26.313 & 7.118 & 29.615 \\
\hline 6 & 2005-06 & 38.837 & 10.096 & 7.111 & 29.566 & 6.728 & 33.360 \\
\hline 7 & 2006-07 & 33.227 & 10.109 & 6.387 & 36.819 & 5.920 & 41.438 \\
\hline 8 & 2007-08 & 47.800 & 10.180 & 8.079 & 20.639 & 7.849 & 22.898 \\
\hline 9 & 2008-09 & 37.339 & 10.244 & 6.929 & 32.360 & 6.521 & 36.343 \\
\hline 10 & 2009-10 & 35.191 & 10.330 & 6.654 & 35.586 & 6.215 & 39.835 \\
\hline 11 & 2010-11 & 31.803 & 9.837 & 6.183 & 37.145 & 5.696 & 42.096 \\
\hline 12 & 2011-12 & 35.903 & 10.220 & 6.747 & 33.982 & 6.318 & 38.180 \\
\hline
\end{tabular}

The proposed relationship above explained the percentage of variance as $89.52 \%$. The recharge of groundwater at $\mathrm{P}=$ 15.28 inch shows that the lowest recharge was found to be 5.310 in the year 2010-2011. Table II explained the relative errors (\%) in the estimation of rainfall recharge from the proposed empirical relationship in comparison with the water balance study. Using this relation, it was found that the relative error values range from 3.680 to 46.020 . But for the Chaturvedi formula (equation 1 and 2), the relative errors almost have the same values as the result above as indicated in Table III.

\section{CONCLUSIONS}

The water balance approach is a good method for assessing the natural groundwater recharge from rainfall. In the present study, empirical relationship has been suggested for estimation of the groundwater recharge from rainfall with a reasonable accuracy. The result of the analysis was found to be reasonable and important as seen in the above paragraph.

Therefore, for a quick assessment of natural groundwater recharge, the Equation 4 is more appropriate especially in a tropical monsoon region such as the Terengganu Malaysia.

\section{ACKNOWLEDGMENT}

Authors are thankful to the Department of Irrigation and Drainage and Department of Minerals and Geosciences Terengganu, Malaysia in providing the data for this work. The authors acknowledge the Postgraduate school Universiti Sultan Zainal Abidin for the provision of transportation for site visit and data collection.

\section{REFERENCES}

[1] C. P. Kumar and P. V. Seethapathi, "Assessment of natural groundwater recharge in upper Ganga Canal command area," Journal of Applied Hydrology, vol. 15, pp. 13-20, Oct. 2002.

[2] M. K. A. Kamarudin, M. E. Toriman, M. H. Rosli, H. Juahir, A. Azid, S. F. M. Zainuddin, N. A. A. Aziz and W. N. A. Sulaiman, "Analysis of meander evolution studies on effect from land use and climate change at upstream reach of Pahang River, Malaysia," Mitigation and Adaptation Strategies for Global Change, vol. 20, pp. 1319-1334, Dec. 2015

[3] M. S. M. Saudia, H. Juahir, A. Azid, M. K. A. Kamarudin, M. F. Kasim, M. E. Toriman, N. A. A. Aziz, C. N. C. Hasnam and M. S. Samsudin, "Flood risk pattern recognition using chemometric technique: A case study in Kuantan River Basin," Jurnal Teknologi, vol. 72, pp. 137-141, Dec. 2014.

[4] M. K. A. Kamarudin, M. E. Toriman, H. Juahir, A. Azid, M. B. Gasim, A. S. M. Saudi, R. Umar, N. H. Sulaiman, F. M. Ata, A. D. Mustafa, M. A. Amran, W. A. Yusoff and F. Azaman, "Assessment of river plan change using RS and GIS technique," Jurnal Teknologi, vol. 76, pp. 31-38, Aug. 2015

[5] N. H. Sulaiman, M. K. A. Kamaruddin, A. D. Mustafa, M. A. Amran, F. Azaman, I. Z. Abidin and N. Hairoma, "Trend analysis of Pahang river using non-parametric analysis: Mann Kendall's trend test," Malaysian Journal of Analytical Sciences, vol. 19, pp. 1327-1334, 2015

[6] S. R. Saghravani, I. Yusoff, S. Mustapha and S. F. Saghravani, "Estimation of groundwater using empirical method: A case study in the tropical zone," Sains Malaysiana, vol. 42, pp. 553-560, 2013.

[7] S. R. Saghravani, S. Mustapha, S. Ibrahim, M. K. Yusoff, M. Azwan and S. F. Saghravani, "Simulation of phosphorus migration in an unconfined aquifer: Universiti Putra Malaysia," Journal of Environmental Hydrology, vol. 17, pp. 1-8, 2009.

[8] A. F. Kamaruddin, M. E. Toriman, H. Juahir, S. M. Zain, M. N. A. Rahman, M. K. A. Kamarudin and A. Azid, "Spatial characterization and identification sources of pollution using multivariate analysis at Terengganu River Basin, Malaysia," Jurnal Teknologi, vol. 77, pp. 269-273, Oct. 2015

[9] M. E. Toriman, M. B. Gasim, Z. Yusop, I. Shahid, S. A. S. Mastura, P. Abdullah, M. Jaafar, N. A. A. Aziz, M. K. A. Kamarudin, O. Jaafar, O. Karim, H. Juahir and N. R. Jamil, "Use of $137^{\text {Cs }}$ activity to investigate sediment movement and transport modeling in river coastal environment," American Journal of Environmental Sciences, vol. 8, pp. 417-423, 2012. 
[10] A. A. Mohamed, S. A. Rahim, D. A. Aitman and M. K. A. Kamarudin "Analysis of seasonal soil organic carbon content at Bukit Jeriau Forest, Fraser Hill, Pahang," Malaysian Journal of Analytical Sciences, vol. 20, pp. 452-460, 2016.

[11] M. K. A. Kamarudin, M. E. Toriman, N. H. Sulaiman, F. M. Ata, M. B. Gasim, A. Muhamad, W. A. Yusoff, M. Mokhtar, M. A. Amran and N. A. A. Aziz, "Classification of tropical river using chemometrics technique: Case study in Pahang River, Malaysia," Malaysian Journal of Analytical Sciences, vol. 19, pp. 1001-1018, 2015.

[12] M. E. Toriman, L. Q. Yun, M. K. A. Kamarudin, N. A. A. Aziz, M Mokhtar, R. Elfithri and K. Bhaktiku, "Applying seasonal climate trends to agricultural production in Tanjung Karang, Malaysia," American Journal of Agricultural and Biological Sciences, vol. 9, pp. 119-126, Jan. 2014

[13] S. A. A. Rashid, M. B. Gasim, M. E. Toriman, H. Juahir, M. K. A Kamarudin, A. Azid and N. A. A. Aziz, "Water quality deterioration of Jinjang river, Kuala Lumpur: Urban risk case water pollution," Arab World Geographer, vol. 16, pp. 349-362, Dec. 2014.

[14] A. S. M. Saudi, A. Azid, H. Juahir, M. E. Toriman, M. A. Amran, A. D. Mustafa, F. Azaman, M. K. A. Kamarudin and M. M. Saudi, "Flood risk pattern recognition using integrated chemometric method and artificial neural network: A case study in the Johor River Basin," Jurnal Teknologi, vol. 74, pp. 159-164, Apr. 2015.

[15] M. K. A. Kamarudin, M. Idris and M. E. Toriman, "Analysis of Leptobarbus hoevenii in control environment at natural lakes," American Journal of Agricultural and Biological Science, vol. 8, pp. $142-148,2013$

[16] F. M. Ata, M. E. Toriman and M. K. A. Kamarudin, "Impact of interception on infiltration and soil moisture in dipterocarp forest and oil palm plantations in Tasik Chini, Pahang," Malaysian Journal of Analytical Sciences, vol. 19, pp. 1084-1092, 2015.
[17] A. Ismail, M. E. Toriman, H. Juahir, S. M. Zain, N. L. A. Habir, A Retnam, M. K. A. Kamarudin, R. Umar and A. Azid, "Spatial assessment and source identification of heavy metals pollution in surface water using several chemometric techniques," Marine Pollution Bulletin, vol. 106, pp. 292-300, May 2016.

[18] W. A. Yusoff, M. Jaafar, M. K. A. Kamarudin and M. E. Toriman, "Land exploration study and water quality changes in Tanah Tinggi Lojing, Kelantan, Malaysia," Malaysian Journal of Analytical Sciences, vol. 19, pp. 951-959, 2015

[19] M. E. Toriman,, F. M. Ata, M. K. A. Kamarudin and M. Idris, "Bedload sediment profile and effect of river bank erosion on river crosssection," American Journal of Environmental Sciences, vol. 6, pp. 292300, Jul. 2013.

[20] A. S. Hameed, T. R. Resmi, S. Suraj, C. U. Warrier, M. Sudheesh and R. D. Deshpande, "Isotopic characterization and mass balance reveals groundwater recharge pattern in Chaliyar river basin, Kerala, India,' Journal of Hydrology: Regional Studies, vol. 4, pp. 48-58, Sep. 2015.

[21] S. R. Saghravani, I. Yusoff, Z. Othman, W. Z. W. M. Tahi, "Estimation of natural groundwater recharge using chlorine mass balance in the north Kelantan River catchment" in Proc. MPSGC'12, 2012

[22] C. Zuh, "Estimation of recharge from radio carbon dating of groundwater and numerical flow and transport modeling," Water Resources Research, vol. 36, pp. 2607-2620, Sep. 2000.

[23] R. S. Chaturvedi, "A note on the investigation of groundwater resources in the western district of Uttar Pradesh," U.P. Irrigation Research Institute, Annual Rep., 1973.

[24] C. P. Kumar, "Estimation of natural ground water recharge," ISH Journal of Hydraulic Engineering, vol. 3, pp. 61-74, Jan. 1977. 